\title{
O AMOR NA POLÍTICA: UM DIÁLOGO ENTRE HANNAH ARENDT E SANTO AGOSTINHO
}

\author{
Love in politics: a dialogue between Hannah Arendt \\ and Saint Augustine
}

Renato Augusto Carneiro Jr.*

Amarás, pois, ao Senhor teu Deus de todo o teu coração, e de toda a tua alma, e de todo o teu entendimento, e de todas as tuas forças; este é o primeiro mandamento. E o segundo, semelhante a este, é: Amarás o teu próximo como a ti mesmo. Não há outro mandamento maior do que estes.

Evangelho S. Marcos, 12; 30-31

\section{RESUMO}

Hannah Arendt (1906-1975) faz diversas referências a Santo Agostinho (354-430) ao longo de suas obras. As idéias do filósofo foram trabalhadas mais profundamente em sua tese de doutoramento, de 1929, $O$ Conceito de Amor em Santo Agostinho. Dividida em três partes distintas - o amor como desejo, o amor na relação entre o homem e Deus e o amor ao próximo - este livro deu a Hannah a oportunidade de analisar a existência humana e a importância do amor na relação do homem com o Criador e com a sociedade. Este tema, do amor, voltaria no livro Homens em Tempos Sombrios, onde analisou a história de João XXIII, entre outros personagens do século XX. Em sua vasta produção, Arendt revela sua forma de pensar política a partir dos termos do filósofo cristão: abandonar-se à fé - nos homens e/ou em Deus - é lidar com coisas da polis de uma posição em que o outro não é considerado um inimigo, mas um irmão. Não cobiçar as coisas terrenas, mas lidar na política com a charitas agostiniana, torna-nos abertos ao diálogo, à conciliação e à aceitação de nossos oponentes. É a política da não-violência ativa, na linha de Gandhi, Luther King e Dom Hélder Câmara, arcebispo de Recife e Olinda, Brasil, nos anos de 1964 e 1985.

Palavras-chave: Amor; Política; João XXIII; Santo Agostinho; Nãoviolência.

* Professor na UniCuritiba e doutorando em História na UFPR. 


\begin{abstract}
Hannah Arendt (1906-1975) made several references to Saint Augustin (354-430) along her academic literature. The philosopher ideas had been analyzed in depth in her PHD thesis, The Concept of Love in Saint Augustin, in 1929. This book is divided in three distinct parts - love as desire, love in the relation between man and God and love between man and the others - giving Arendt the opportunity to analyze the human existence and the importance of love in the relationship among men and God and among men and the society. This theme, love, came back on the book Men in The Dark Times, where Hannah wrote about the Pope John XXIII, besides some other twentieth century great characters. In her extensive literature, Arendt revealed the way of her thinking about politics from the Christian philosopher: abandoning oneself to the faith - at the mankind and/or at God - means to deal with the polis things from the position of the other is not considered an enemy, but a brother. Don't covet the terrestrial things, but deal with politics using the augustinian charitas make us opened to dialog, to conciliation and to acceptation of ours opponents. It is the politics of the active nonviolence on the way of Gandhi, Luther King and Dom Hélder Câmara, archbishop of Recife and Olinda, Brazil, from 1964 to 1885.
\end{abstract}

Keywords: Love; Politics; John XXIII; Saint Augustin; No-violence.

Hannah Arendt sempre foi, ao longo de sua vida, uma estudiosa da existência humana. Política, liberdade, ódio, preconceito, amizade e amor foram alguns dos aspectos sobre os quais refletiu para entender nossa trajetória sobre a Terra. Não à toa, sua primeira obra de fôlego tratou do amor. Ainda muito jovem, aos vinte e dois anos, defendeu sua tese de doutoramento, em novembro de 1928, com o título O Conceito de Amor em Santo Agostinho. ${ }^{1}$

Mas por que uma judia alemã estudaria Santo Agostinho em seu doutoramento? Nascida em 1906, em Hanover, Alemanha, numa família de judeus educados e "assimilados" pela cultura alemã do seu tempo, com alguma inclinação esquerdista no que diz respeito à política e certo afasta-

1 ARENDT, H. O conceito de amor em Santo Agostinho. Lisboa: Instituto Piaget, 1997. 
mento no plano religioso, o que não impediu que a filha única de Martha e Paul Arendt recebesse a devida educação religiosa em uma sinagoga. Suas indagações que a levariam a escrever, na certa, seguiam a tendência de seus professores e orientadores, Martim Heidegger e Karl Jaspers, principalmente, de buscar nos filósofos cristãos, como Agostinho, Pascal e Kierkegaard, fontes para repensar o problema da existência. Havia, à época, todo um entusiasmo em investigar as obras do bispo de Hipona nos meios acadêmicos e filosóficos alemães, igualmente entre teólogos católicos e protestantes. ${ }^{2}$

Arendt, no entanto, encarou este seu trabalho da forma como uma pensadora ainda pouco madura o faria. Nas palavras de sua principal biógrafa, ElizabethYoung-Bruehl: "A tese de doutorado de Hannah Arendt, Der Liebesbegriff bei Augustin, impressa em caracteres góticos, recheada de citações latinas e gregas não traduzidas e escrita em prosa heideggeriana, não é uma obra fácil de entender". ${ }^{3}$ Depois da publicação, em 1929, pela editora Springer, de Berlim, esta obra permaneceu guardada, para quando Hannah tivesse tempo para providenciar sua revisão e apenas nos anos 1960, mais de duas décadas após sua chegada aos Estados Unidos, é que foi retomada, numa tradução que não chegou a satisfazer a autora.

Em sua obra, Julia Kristeva divulga o relatório reservado do orientador Karl Jaspers, acerca do trabalho de sua orientanda. Segundo ele, à época, parecia-lhe que sua aluna,

[...] está apta a sublinhar o essencial, mas que ela, simplesmente, não reuniu tudo o que Agostinho disse sobre o amor. [...] Alguns erros surgem nas citações. [...] O método exerce alguma violência sobre o texto. [...] A autora quer, através de um trabalho filosófico de idéias, justificar sua liberdade com relação às possibilidades cristãs, que, no entanto, a atraem. [...] Não merece, infelizmente, a mais alta menção [cum laude]. Efetivamente, Arendt parece privilegiar, em Agostinho, o filósofo, em detrimento do teólogo. ${ }^{4}$

2 SOUSA, J. P. de. A presença de Santo Agostinho na obra de Hannah Arendt. Estudos, Lisboa, n. 2, p. 243-267, 2004.

3 YOUNG-BRUEHL, E. Hannah Arendt: por amor ao mundo. Rio de Janeiro: RelumeDumará, 1997. p. 427.

4 KRISTEVA, Julia. $O$ gênio feminino: a vida, a loucura e as palavras. Rio de Janeiro: Rocco, 2002. p. 41. 
Para Hannah Arendt não importava o Agostinho religioso, importava-lhe o filósofo que discorreu sobre o amor, hierarquizando-o. Dele, Arendt se utilizará principalmente do conceito de amor mundi, o amor no mundo, que por fim permearia o conjunto da obra da autora, até seu último livro, postumamente publicado, A Vida do Espírito. Tão forte seria isto na vida de Hannah, ela mesma profundamente influenciada pelo amor, como diria nesta última obra, referindo-se mais uma vez a Santo Agostinho: "O amor é o peso da alma, sua lei da gravidade, aquilo que leva o movimento da alma ao repouso". ${ }^{5}$ Young-Bruehl, usaria o conceito de amor mundi no título de sua biografia sobre Hannah, reconhecendo ser este o conceito mais central na obra de Arendt.

É preciso que se note também que nesta fase da vida de Hannah Arendt a política ainda não era uma preocupação da filósofa que ela buscava ser. Aos vinte e poucos anos, no período entre-guerras, apaixonada por um de seus professores, ainda não se antevia a autora vigorosa na denúncia do totalitarismo, da violência e do ódio. Mas o amor que, então, analisava em Santo Agostinho, seria o fio condutor de sua vida pessoal e intelectual, voltando a ele até seus últimos escritos.

Santo Agostinho é considerado um dos maiores filósofos da Igreja, tendo escrito mais de 400 sermões, 270 tratados doutrinários, sob a forma de cartas, e 150 livros. Nasceu em Tagaste, na Numídia, hoje Argélia, na época província romana ao norte da África, em 13 de novembro de 354; era o primogênito do pagão Patrício e da cristã fervorosa Mônica, mais tarde reconhecida como santa pela Igreja. Entre todos os seus escritos, duas de suas obras são consideradas fundamentais para o desenvolvimento do cristianismo: Confissões e A Cidade de Deus. "Nenhum outro teólogo tem sido mais influente no Ocidente como Santo Agostinho. Ele assinalou o caminho espiritual-teológico para a Igreja até aos tempos modernos". ${ }^{6}$ A ele caberia a introdução do conceito do amor na Igreja, como fundamento para a religião cristã, mais ainda que o respeito às tradições: "Amai a Deus e fazei o que quiserdes", segundo uma famosa frase de Agostinho, mostra a

5 ARENDT, H. A vida do espírito. Rio de Janeiro: Relume-Dumará, 1993. p. 256. A frase de Agostinho era: "Meu peso é meu amor, é ele que me leva onde quer que eu vá."

6 LINDBERG, C. História do cristianismo. Lisboa: Teorema, 2007. p. 53. 
dimensão que o amor teria em suas obras. ${ }^{7}$ Mas a que tipo de amor o filósofo se referia? $\mathrm{Ou}$, ainda, existiria mais de um tipo de amor? "Numerosos termos declinam o conceito de amor em Agostinho: amor, desejo (com suas duas variantes, appetitus e libido), caridade, concupiscência, formando uma verdadeira 'constelação do amor' (...)". ${ }^{8}$

Hannah Arendt buscou compreender, pois, o significado da palavra amor, a partir do legado de Santo Agostinho. Ela partiu do princípio que o amor resulta da posição do cristão frente a Deus, ao próximo e a si mesmo. Mais que cristão, no entanto, amor foi um conceito desenvolvido por São Paulo, que aproximou a nascente religião dos gentios, isto é, aos demais povos e culturas do Oriente Médio, mas principalmente aos gregos, contrariando a posição inicial das comunidades cristãs de que a revelação da Boa Nova era destinada aos judeus que se convertessem à mensagem de Jesus, o novo Messias há tanto tempo esperado por eles.

O que havia de mais forte na mensagem cristã, de verdadeiramente revolucionário, era a noção de libertação das antigas leis, do temor a um Deus poderoso e por vezes vingativo do Antigo Testamento, centrando no amor a base da religião que se espalharia pelo mundo a partir dos ensinamentos de Cristo, mas que ao longo dos tempos seriam transformados pela Igreja num instrumento de poder da instituição sobre seus fiéis.

Eles não compreenderam [...] que o "não faças aos outros o que não queres que te façam a ti" não era de forma alguma suscetível de interpretações diversas em função da sua pertença a tal ou a tal nação. Com efeito, se se aplica este princípio ao amor de Deus, então é o fim de toda a ação vergonhosa; sendo aplicado ao próximo, é o fim de todo o crime. ${ }^{9}$

Mas, analisando em si a obra em questão, O Conceito de Amor em Santo Agostinho, vê-se que ela se divide em três partes distintas: o amor como desejo (appetitus); o amor na relação entre o homem e o Deus criador 2002. p. 42.

7 LINDBERG, C. História do cristianismo. Lisboa: Teorema, 2007. p. 62.

8 KRISTEVA, Julia. $O$ gênio feminino: a vida, a loucura e as palavras. Rio de Janeiro: Rocco,

9. ARENDT, H. O conceito de amor em Santo Agostinho. Lisboa: Instituto Piaget, 1997. p. 9. 
(creature et creator) e o amor ao próximo, ou a vida em sociedade (vita socialis). Hannah identificaria que o amor como desejo e cupidez seriam concepções pré-teológicas, ou pré-conversão, enquanto que o amor como vizinhança ou como relação ao próximo estaria mais ligado aos tempos cristãos.

Na primeira parte de sua tese, a do amor como desejo, Hannah analisa a concepção agostiniana da existência humana e de seu fim último, que é a felicidade. Ele percebe que a vida não é desejada pelo indivíduo, à medida que ele a tem, mas que, como a possibilidade de perdê-la no futuro é real, o indivíduo passa a ver a vida como objeto de desejo, enquanto o medo da morte - ou o medo de perder a vida - torna-se uma forma de expressar o amor pela vida. Da mesma maneira, seu pensamento se desenvolve pelo mecanismo que faz os homens desejarem alguma coisa. Ao querer algo que está fora de si, o homem investe seus esforços para possuir o que seu apetite lhe indica. Conquistando-o para si, cessaria o desejo desta coisa, a não ser que a possibilidade de sua perda seja real. Assim, o amorapetite transforma-se em medo e o medo, sendo o mal do amor, já não é o amor que motivou a conquista.

"Os bens temporais (presentes no tempo) nascem e morrem independentemente do homem, que a eles está ligado pelo desejo". ${ }^{10}$ Todo o presente é determinado, não apenas pelo futuro (o não-ainda) como tal, mas também por acontecimentos precisos, temidos ou esperados no futuro. Dessa forma, o presente perde toda a quietude, toda a possibilidade de prazer e, na mesma medida, sua significação original.

Não se pode pôr a felicidade nos bens materiais, deste mundo, pois todos são finitos em si e mesmo que tivessem permanência, a própria vida humana é também finita. Da mesma forma, colocar o bem supremo, a felicidade, na existência do outro, numa pessoa qualquer, por mais cara que seja, pela transitoriedade da vida, é uma aposta sem sentido, pois se tem a certeza de sua não permanência no futuro. Não se possui nada, nem ninguém, nem a própria existência, que não esteja destinada à morte. Este pensamento afasta toda a paz de espírito, toda a possibilidade de felicidade. Segundo Agostinho, este amor, este apego ao terreno, ao material, é um

18.

10 ARENDT, H. O conceito de amor em Santo Agostinho. Lisboa: Instituto Piaget, 1997. p. 
falso amor, por se prender ao mundo. Ele o chamava cobiça (cupiditas). Ao amor puro, que aspira à eternidade e à felicidade eterna, ele chamava de caridade (charitas).

Caridade e cobiça diferenciam-se pelo objeto que visam e não pelo como do próprio visar. Descrevem desde logo a pertença a qualquer coisa e não à atitude, o habitus. $\mathrm{O}$ homem é aquilo que se esforça por atingir. $\mathrm{O}$ amor é a mediação entre o que ama e aquilo que ama; o que ama nunca está isolado daquilo que ama, isso lhe pertence. O desejo daquilo que é a ordem do mundo é mundano, pertence ao mundo. O que cobiça decidiu ele próprio, através da sua cobiça, a sua corruptibilidade, enquanto a caridade, visto que tende para a eternidade, tornase ela própria eterna. Se é verdade que todo o homem particular vive isolado, ele tenta no entanto ultrapassar sempre este isolamento através do amor; mas também não é menos verdade que a cobiça faça dele um habitante deste mundo ou que a caridade o obrigue a viver num futuro absoluto, mundo que ele habitará. ${ }^{11}$

A beatitude, ou felicidade, seria, pois, não apenas a posse do bem, mas também a possibilidade de sua não-perda. A vida constantemente ameaçada pela morte não é vida, uma vez que nunca deixa de correr o risco de perder o que é; aquilo que até sabe que tem que perder um dia. "A vida que é eterna e feliz é a Vida propriamente dita". ${ }^{12}$ A vida que não pode ser perdida, ou que não se importa de ser perdida, é a única vida feliz.

A vida terrestre é uma morte vivente ou uma vida morredoura, uma vida posta à determinação da morte. Mas se se tem medo de ver pôr termo à saúde e à vida, isso já não é, nem nunca mais será a vida. Pois já não é mais viver sem cessar, mas temer sem cessar. Não há nada mais a amar do que a ausência de medo, e esta só existe na perfeita quietude, de que nenhum acontecimento que o futuro reservasse conseguiria abalar. É a eternidade que harmoniza o coração humano.

25 .

11 ARENDT, H. O conceito de amor em Santo Agostinho. Lisboa: Instituto Piaget, 1997. p.

12 Ibid., p. 19. 
Um engano comum, depois de Agostinho, era imaginar o mundo e a libido, ou o desejo do mundo, como maus em si. O que prejudica o homem não é o que está fora dele, mas sua dependência a estas coisas transitórias, que se transforma no medo de perdê-las, que o aprisiona ao futuro da não-posse. A cobiça no coração pode fazer do homem escravo de seus desejos, mas a caridade desprendida o liberta, justamente porque não tem medo do futuro, mas a ele aspira.

A realização é a beatitude, que não consiste em amar, mas em fruir daquilo que é amado e desejado. Todo o amor é tensão dirigida para esta fruição. No entanto, ninguém é feliz se não fruir do que ama. [...] Fruir é estar perto do objeto desejado, firme e sem inquietude. ${ }^{13}$

Ou seja, sem o medo da perda, sem medo do futuro e da morte.

Onde se pode, então, encontrar a quietude da não-cobiça do que está no mundo? Fora do mundo, ou dentro de si, na busca de Deus em si mesmo é que o homem pode ser feliz. Ao voltar-se para seu interior, o homem encontra a Deus. Encontrando Deus, o homem encontra o que lhe falta, o que o projeta ao futuro.

Efetivamente, o que é que se quer dizer com falar de si mesmo através de Ti, senão aprender a conhecer-se a si mesmo? E eu procuro-Te fora de mim, e não encontro o Deus do meu coração. Pois Ele estava dentro e eu fora. Em seguida, exortado a regressar a mim mesmo, penetrei no meu próprio interior, sob Tua condução; e isso foi-me possível por que Tu vieste ajudar-me. ${ }^{14}$

Esse exercício de introspecção, da busca de Deus dentro de si mesmo, afastando-se das coisas terrenas, seria outra contribuição de Agostinho à fé cristã, influenciando muitas gerações e presente até nos tempos atuais.

Esta necessária ligação com o Criador será mais detalhada na sequiência da tese sobre Santo Agostinho. Na segunda parte do trabalho, Hannah 36.

13 ARENDT, H. O conceito de amor em Santo Agostinho. Lisboa: Instituto Piaget, 1997. p.

14 AGOSTINHO. Confissões. In: ARENDT, op. cit., p. 29. 
Arendt analisa o amor na relação entre homem e seu Criador, reconhecendo a dependência da criatura pelo Criador. Ela explica, neste capítulo, como a fé é o conceito central da vida do indivíduo, segundo Agostinho, retomando em parte o que já analisara no capítulo anterior.

A busca pela felicidade remete ao Criador, ao momento da criação, portanto ao passado (o não-mais). É possível ser feliz rememorando a fonte da existência. Esta fonte está não apenas na própria história pessoal, mas na de toda humanidade, pois na criação de Adão, reconhecemo-nos como irmãos de um mesmo Pai. Em Adão, no entanto, ao aspirar às coisas materiais, terrenas, na cobiça do fruto da árvore proibida, partilha-se com ele o medo da morte, da perda do objeto do desejo.

A origem do homem, desta forma, mais serviria para levá-lo ao pecado, a partir do pecado original. O amor de Deus, fazendo-se carne, humano em seu Filho, redime a todos deste mal e a todos recupera por sua Graça. Não seria por mérito individual, mas pela Graça divina, que se poderia atingir o destino último na felicidade. O que pode impedir o homem neste trajeto à eternidade seria sua própria vontade, o livre-arbítrio. Rememorar a origem, principalmente a segunda origem, em Cristo, aceitando assim a Graça divina, seria a única possibilidade de alcançar a verdadeira felicidade.

A vida feliz só pode ser alcançada a partir do regresso (redire) à sua própria origem. $\mathrm{O}$ regresso a si é idêntico ao regresso ao Criador. O homem ama-se a si próprio relacionado-se com Deus enquanto seu Criador. Tal como o desejo que aspira à vida feliz só adquire o seu sentido na memória que remonta para além da vida terrestre e mundana, também a criatura, no seu estado de criatura, só adquire o seu sentido através do Criador, que existia antes de ter sido criada, enquanto a sua origem. Pois, na medida em que o Criador é anterior ao criado, a origem já está sempre lá; e como a criatura nada seria sem esta origem, a relação com o anterior é aquilo que em primeiro lugar a constitui como ente. [...] Ser criado significa que a criatura não tira o seu ser dela própria, mas de Deus, entendido pura e simplesmente como o ser, o ser supremo. ${ }^{15}$

15 AGOSTINHO. Confissões. In: ARENDT, H. O conceito de amor em Santo Agostinho. Lisboa: Instituto Piaget, 1997. p. 70. 
A Graça divina dá a possibilidade de escolher onde buscar a felicidade. Cabe aos homens elegerem o objeto de seu amor, aquilo que pensa que os fará felizes. Como já se viu, o mal não está no mundo ou nos objetos do mundo, mas onde colocam seus corações. "Não ajunteis tesouros na terra, onde a traça e a ferrugem tudo consomem, e onde os ladrões minam e roubam. Porque onde está teu tesouro, aí também estará o teu coração" (MATEUS, 6: 19-21).

$\mathrm{O}$ amor às coisas presentes, de dentro do mundo, que Santo Agostinho chamava de falso-amor ou cobiça, opõe-se ao amor justo que aspira à eternidade e ao futuro absoluto, chamado de caridade. A vida sem morte, portanto, só é possível no eterno, em Deus. No Deus da caridade.

A caridade, portanto, faz a ligação entre o homem e Deus, enquanto a cobiça liga o homem ao mundo. O que é a caridade? É a opção pela morte deste mundo, na imitação de Cristo, para a doação da vida aos demais. "Quem achar a sua vida perdê-la-á; e quem perder a sua vida, por amor de mim, achá-la-a" (MATEUS, 10: 39).

A morte, que só ela, excetuando Deus, tem o poder de subtrair o homem ao mundo, reenvia à eleição no seio do mundo. Temese a morte porque se ama o mundo (amor mundi); a morte aniquila não só qualquer posse do mundo, mas também todo o desejo de amar qualquer coisa por vir que se espera do mundo. A morte destrói a relação natural no mundo da qual o amor mundi é a expressão. Por isso, a morte é de modo puramente negativo, de tal maneira poderosa, separando-nos do mundo, como o amor de que se apodera em Deus o próprio ser. "Esse amor constitui precisamente a nossa morte no século e a nossa vida em Deus. Com efeito, se se trata de uma morte logo quando a alma deixa o corpo, como é que não se trataria de uma morte na qual nós renunciamos à nossa afeição ao mundo? O amor tem, pois, a força da morte." 16

Só no amor tem-se a possibilidade de se fazer abdicar da vontade própria, desfazendo-se do orgulho de si e é justamente esta renúncia que

16 ARENDT, H. O conceito de amor em Santo Agostinho. Lisboa: Instituto Piaget, 1997. p. 95. A citação de Arendt, dentro desta citação, remete-nos às epístolas de São João. 
permite alcançar a Graça divina. Na renúncia a si é que a criatura abandona-se no Criador, deixando de lado o livre-arbítrio que lhe permitiria praticar ou permitir o mal. Assim, quando ama, é o amor do e ao Criador que nos faz amar e não apenas nossa vontade para com o próximo.

Esta renúncia a si exprime-se no comportamento face ao mundo. O mundo é amado enquanto criado; amando no mundo, a criatura ama o mundo como Deus. Esta aí a realização da renúncia a si que volta a dar a cada um no mundo, e também a si próprio, o seu sentido verdadeiro proveniente de Deus. Esta realização é o amor ao próximo. ${ }^{17}$

O amor ao próximo é o que liga o homem de fato ao mundo do Criador, pois nele é que se exprime o amor a Deus. Será, pois, no amor verdadeiro, na caridade, que se pode refazer a ligação com o mundo de acordo com a vontade do Criador, amando a todos os homens sem distinção, pois a renúncia ao mundo faz percebê-lo como um deserto, onde não há como diferenciar entre este e aquele, onde não prevalece a cobiça, a inveja e o desejo de posse. $\mathrm{O}$ amor ao próximo não se dá pelo fato dele estar no mundo, mas pelo fato de ter sido criado, como todos, pelo mesmo Criador, tendo no amor de Deus a mesma origem.

A morte deixa de ter significado, pois como o amor ao próximo não se dá pelo que ele é, mas como se percebe nele o que é eterno. "Para o amor, a morte não têm importância, porque todo o ser só é uma razão para amar a Deus. [...] Neste amor ao próximo, não é exatamente o próximo que é amado, mas o próprio amor." 18

A terceira parte da tese de Arendt é que trata, com mais detalhes, da vida em sociedade, do amor em relação aos outros. Se o homem se isola do mundo na relação criatura-Criador, é no relacionamento criatura-criatura, mediado pelo exemplo de Cristo, criador que se fez criatura, que o homem rompe seu isolamento e torna possível a vida em sociedade. O capítulo Vita Socialis trata, portanto, que é na direção do outro, do próximo, que

112.

17 ARENDT, H. O conceito de amor em Santo Agostinho. Lisboa: Instituto Piaget, 1997. p.

18 Ibid., p. 117. 
o homem pode superar o pecado e a morte, como vimos, uma vez que esta graça só pode ser alcançada na imitação de Cristo.

\begin{abstract}
"Eles viram, nós não, e, no entanto pertencemos a uma mesma comunidade, pois temos uma fé comum." A verdadeira sociedade está fundada sobre o fato da fé comum. [...] fundada sobre qualquer coisa que por princípio não é o mundo, é deste modo comunidade com o outro não porque ele esteja aí realmente no mundo, mas devido a uma possibilidade específica; depois, como esta possibilidade é a mais radical do ser do homem, esta comunidade da fé comum que se realiza no amor mútuo, exige o homem por inteiro [...] tal como Deus o exige. ${ }^{19}$
\end{abstract}

Ao nascer, o homem se liga, em primeiro momento, à comunidade humana mais ampla, aquela fundada em Adão, apartada de Deus pelo pecado original, na desobediência do Criador. Depende, assim, dos outros homens, através das diversas gerações, numa sucessão de sociedades alicerçadas sobre os mortos e com os mortos. Isto coloca a sociedade como histórica. O resgate desta natureza pecadora, pela graça do Criador, que concedeu seu Filho para a remissão deste pecado de afastamento de Deus, traz o homem a uma outra realidade. Todos são chamados ao amor pelo Filho que nasceu entre os homens, livre do pecado original, por sua dupla origem, indissociavelmente humana e divina.

Todo o nascimento traz, desta forma, a possibilidade do novo. Hannah voltaria a este tema em vários momentos do conjunto de sua obra, em especial no livro A Condição Humana. Para ela, esta foi realmente a boa nova trazida pelos evangelhos: "Nasceu uma criança entre nós!" ${ }^{20}$ No nascimento de novos homens dá-se o milagre da esperança de salvação deste mundo da ruína a que se destina, da morte, pois podem trazer em si a ação de que são capazes pelo fato de terem nascido. A esperança não é, pois, a última ilusão entre os males da caixa de Pandora, como acreditavam os gregos, mas a possibilidade real de mudança.

19 ARENDT, H. O conceito de amor em Santo Agostinho. Lisboa: Instituto Piaget, 1997. p. 152. A citação da autora refere-se às epístolas de São João.

20 ARENDT, H. A condição humana. Rio de Janeiro: Forense Universitária, 2004. p. 259. 
Para Arendt, a temporalidade, longe de precisar ser superada para que o homem seja, é a fonte de sua possibilidade de ação, na qual o seu ser é intensificado. É como se citasse para Agostinho (e Heidegger) um dos trechos que mais apreciava em Píndaro: 'Torna-te o que és' - isto é, reconhece com gratidão o que o fato de ter nascido te proporciona. ${ }^{21}$

O mundo pode ser salvo, sem que o mérito possa recair sobre este ou aquele grupo humano. A salvação só é possível por Cristo e esta Graça é dada por igual, sem distinção de raça, gênero e crença. Cristo é, pois, o fundador da Cidade Celeste, como Adão foi da Cidade Terrena. Resta seguir seu amor, na renúncia de nós mesmos e na aceitação do outro, não pelo outro, mas pelo amor de Deus que nele se manifesta. A vida nova fundada em Cristo é determinada pelo amor mútuo, quando o próximo passa a ser um irmão. A caridade, dever do cristão, fundamenta-se na fraternidade.

A passividade pode levar a aceitar a morte, como descendência de Adão. A possibilidade de salvação, da vida eterna, está colocada, pois, na Graça, no amor que nunca cessa, na caridade. Ao se afastar dela, pelo livrearbítrio, o homem coloca-se em risco não apenas da morte, mas da morte eterna, por se afastar igualmente da origem primeira, que está no Criador. Isso quer dizer que a caridade exige ação, a opção de um ato volitivo de atuar em favor de Deus e de suas criaturas. Mais adiante, veremos na prática da política o que pode significar essa opção.

Ao se entender que o estudo de $O$ Conceito de Amor em Santo Agostinho pertence a uma fase bem determinada da juventude de Hannah Arendt, que a ela voltaria ao longo de toda a sua existência, entende-se também como algumas das referências carregadas pela autora em seu íntimo pensar tiveram a marca deste tempo. O pensamento de Hannah não se distancia do que viveu ela própria, judia na Alemanha nas décadas anteriores à Segunda Guerra, apátrida e, mais tarde, cidadã americana.

Terminado este trabalho, em 1928, Hannah Arendt pretendeu capacitar-se para lecionar numa universidade alemã. Sua intenção pareceulhe próxima quando ganhou uma bolsa, por indicação de seus professores,

21 YOUNG-BRUEHL, E. Hannah Arendt: por amor ao mundo. Rio de Janeiro: RelumeDumará, 1997. p. 431. 
para elaborar uma nova tese, Rahel Varnhagem: a vida de uma judia. Agravava-se, no entanto, a situação da República de Weimar e a ascensão do Partido Nacional-Socialista na Alemanha acabou por levar Hannah a buscar, mais tarde, o exílio. Este seu texto só seria publicado muitos anos mais tarde, quando ela já morava nos Estados Unidos.

Tendo se casado com o filósofo judeu Günther Stern, Hannah se mudaria para Frankfurt, onde tomaria contato com as idéias de Marx, Lenine, Trotski e Rosa de Luxemburgo. A partir de 1933, quando da chegada dos nazistas ao poder, Hannah Arendt viveria 18 anos como apátrida, depois de fugir de Berlim, passando por Praga, Genova, Paris e Portugal, alcançando, por fim, a América.

Em Paris, travou contato com organizações sionistas e passou a trabalhar com a Juventude Aliyah, entidade criada para preparar jovens a emigrarem e se estabelecerem na Palestina. Em 1936, ela conheceu Heinrich Blücher, ativista operário, que se tornaria seu segundo marido. Ele foi o responsável pela guinada de Hannah para o ativismo político, para além das questões judaicas e sionistas.

Em maio de 1940, pela colaboração francesa com os nazistas, Hannah e Blücher foram internados em um campo de refugiados no sul da França. De lá conseguiram alcançar os Pirineus onde ficaram aguardando o visto para Hannah entrar em Portugal. Esperariam ainda três meses em terras lusas, antes de embarcarem para Nova Iorque, em maio de 1941.

Em 1942, o casal tomaria conhecimento dos campos de concentração e extermínio alemães. Tornando-se cidadã americana em 1951, Hannah viveu naquele país até o fim de sua vida, em 1975, trabalhando até então como professora de diversas universidades americanas. Neste período, desenvolveu As Origens do Totalitarismo; Entre o Passado e o Futuro; Eichmann em Jerusalém: sobre a banalidade do mal; Sobre a Violência; A Condição Humana; Sobre a Revolução; Crises da República e Homens em Tempos Sombrios, além de diversos ensaios, artigos e de ter proferido dezenas de palestras.

No livro Homens em Tempos Sombrios, Hannah traçou o perfil de alguns homens ilustres do século XX. Entre eles, Ângelo Roncalli, o papa João XXIII. Ao descrevê-lo, a autora exprime sua dúvida, fazendo eco a uma senhora romana: como a Igreja havia permitido a um verdadeiro cristão sentar-se no Trono de Pedro? Neste texto, Arendt revela algumas características do papa e de sua forma de pensar, a partir dos termos de Santo 
Agostinho, mesmo que lhe parecesse estranho o cristianismo frente a uma Igreja comprometida com os poderes deste mundo.

No Conclave de 1958, convocado após a morte de Pio XII - papa que governou a Igreja no duro período da Segunda Guerra e a quem se fazia inúmeras críticas sobre sua atuação, na pouca resistência ao nazismo - ocorreu um impasse. O Vaticano precisava mudar sua imagem frente ao mundo, sem perder o controle das mudanças, mas os cardeais ali reunidos não encontravam um nome confiável para conduzir esta nova fase da Igreja. Ângelo Roncalli, patriarca de Veneza, aos 76 anos, não constava das relações dos papabile - sequer os alfaiates da Cúria Romana tinham vestes apropriadas para ele - e sua eleição pareceu à época um compromisso de provisória transição, pois seu pontificado anunciava-se curto, devido a sua idade avançada para o cargo. No entanto, promoveu, nos cinco anos em que esteve no Trono de Pedro, a maior revolução que a Igreja Católica conheceu por séculos.

Homem simples, de família camponesa de Bérgamo, quarto de treze irmãos, o jovem Ângelo descobriu cedo sua vocação para o sacerdócio. ${ }^{22}$ Seu Diário de uma Alma, onde relata sua própria vida e suas observações sobre ela, publicado em 1965, é, segundo Arendt,

[...] um livro estranhamente decepcionante e estranhamente fascinante. Escrito, em sua maior parte, em períodos de recolhimento, compõe-se, de forma extremamente repetitiva, de efusões e auto-exortações piedosas, "exames de consciência" e registros de "progressos espirituais", com raríssimas alusões a acontecimentos reais, apresentando-se ao longo de páginas e páginas, como um manual elementar sobre o modo de ser bom e evitar o mal. ${ }^{23}$

Apesar de pregar por cerca de dois mil anos a imitação de Cristo, a Igreja Católica, principalmente após o período da Contra Reforma, se comportava como uma instituição à qual mais interessa o atendimento aos dogmas que a simplicidade da fé, pregada por Cristo. Não se pode dizer

22 Os dados biográficos de João XXIII foram retirados do site do Vaticano: <www.vatican.va>.

23 ARENDT, H. Homens em tempos sombrios. Lisboa: Relógio D’Água, 1991. p. 73. 
que o "abandonar-se à fé", presente em Agostinho, fosse o modelo seguido pelo Vaticano e pela Cúria Romana em geral. "Não por recear conscientemente os elementos anárquicos que um modo de vida genuinamente cristão comporta, mas simplesmente por pensar que 'sofrer e ser desprezado por Cristo e com Cristo' era má política". ${ }^{24}$

Ainda assim, sendo em sua maneira humilde, contrário à prática vigente junto a seus pares, Roncalli inexplicavelmente subia na hierarquia. Tendo recebido a ordenação episcopal a março de 1925, em Roma, Ângelo Roncalli iniciou o seu ministério na Bulgária, onde permaneceu até 1935, quando foi transferido e nomeado Delegado Apostólico na Turquia e Grécia. Ele se encontrava na Grécia quando irrompeu a Segunda Guerra Mundial, que ficou devastada pelos combates. Procurou dar notícias sobre os prisioneiros de guerra e salvou muitos judeus com a "permissão de trânsito" fornecida pela Delegação Apostólica, conseguindo que o governo turco não enviasse cem crianças judias de volta à Alemanha, de onde haviam fugido. Em 1944, Pio XII nomeou-o Núncio Apostólico em Paris. Anos depois, em 1953, foi elevado a Cardeal e enviado a Veneza, como Patriarca da cidade.

Desde o início de seu pontificado, no Outono de 1958, era o mundo inteiro, e não apenas os católicos, que tinham os olhos postos nele, pelas razões que ele próprio enumera: primeiro, por ter "aceitado com simplicidade a distinção e o fardo", depois de sempre ter tido "o maior cuidado [...] em evitar tudo o que pudesse chamar as atenções sobre a minha pessoa". Segundo, por ter "conseguido [...] pôr imediatamente em prática certas idéias que eram [...] perfeitamente simples mas de grande alcance e cheias de implicações para o futuro". Mas embora segundo seu próprio testemunho, a "idéia de realizar em Concílio Ecumênico, um Sínodo Diocesano, e a revisão do Código do Direito Canônico" lhe tivessem ocorrido "sem qualquer espécie de premeditação", sendo até "absolutamente contrária a todas as [suas] anteriores convicções [...] sobre o assunto", tal empreendimento surgiu aos olhos de todos quanto o observavam como manifestação quase lógica ou, pelo menos, natural, do homem e da sua extraordinária fé. ${ }^{25}$

24 Ibid., p. 74.

25 ARENDT, H. Homens em tempos sombrios. Lisboa: Relógio D’Água, 1991. p. 75-76. 
A convocação em 1959 do Concílio Vaticano II, que se completaria somente após sua morte, sob o pontificado de Paulo VI, em 1965, trouxe o chamado aggiornamento, ou seja, a atualização da Igreja no século XX, fazendo-a, de certo modo, mais partícipe da modernidade, tornando-a mais aberta a uma maior participação dos leigos, na simplificação dos ritos e na busca de um maior ecumenismo junto às demais religiões, deixando de lado a Igreja da Neocristandade ${ }^{26}$, triunfalista e descolada das necessidades cotidianas de seus fiéis.

A simplicidade de Roncalli ficava ainda mais aparente, segundo Hannah, quando se conhecem as histórias que circulavam em Roma, no fim de seus dias, na agonia da morte, pela população da cidade que o adorava, chamando-o de "papa da bondade". Ela descreveu várias histórias sobre João XXIII. Uma delas diz que, tendo ouvido um dos encanadores, que faziam reparos na residência papal, praguejar em nome de toda a Sagrada Família, o papa foi até ele e perguntou-lhe com educação: "Precisa falar assim? Não pode dizer merda como todos nós?" ${ }^{27}$ Outra, dando conta de sua irreverência frente sua própria Cúria, ao conversar com um jovem padre estrangeiro, que se esforçava por fazer boa figura às autoridades vaticanas, teria o papa dito: "Meu querido filho, pare de se preocupar tanto. Pode ter certeza de que no dia do juízo Jesus não lhe vai perguntar: E como é que te deste com o Santo Ofício?" ${ }^{28}$ Quando reclamou do fechamento dos jardins do Vaticano nos momentos em que fazia seu passeio diário e receber a resposta que não ficava bem à sua dignidade expor-se aos olhares das pessoas comuns, teria perguntado: "Porque é que as pessoas não hão de me ver? Eu não me porto mal, pois não?" 29

26 Para entender o que significava à época "Igreja da Neocristandade", tomamos o texto de Giacomo Martina:

Pio XI julgava ainda possível, em pleno século XX, a realização de um Estado Católico, ou, em outros termos, pensava poder salvar ou reconstruir a cristandade, há muito tempo desaparecida. Por seu temperamento autoritário e por sua formação, que tinha amadurecido no final do século XIX, no período de Leão XIII, o Pontífice pensava que esse ideal fosse reconhecido e respeitado, que não só se reconhecesse a liberdade da Igreja, mas que se atribuísse a ela um poder e um regime de privilégio especial [...]. (História da Igreja: de Lutero a nossos dias. São Paulo: Loyola, 1997. v. IV, p. 142).

27 ARENDT, H. Homens em tempos sombrios. Lisboa: Relógio D’Água, 1991. p. 77.

28 Ibid., p. 79.

29 Ibid., p. 80. 
Em ocasiões mais formais, nem por isso João XXIII deixava de expor seu lado mais sincero, sem esconder no fundo a sagacidade do camponês. Ao concluir uma extremamente polêmica audiência dada a representantes da União Soviética, encabeçada pela filha e o genro do presidente Nikita Krushchov, em março de 1963, João XXIII disse: "E agora, com vossa licença, chegou o momento para uma pequena bênção. Afinal de contas, uma bençãozinha não faz mal a ninguém. Aceitai-a como vos é dada".

Consta, também, que ao receber uma primeira delegação judaica depois de muitos anos no papado, João XXIII teria dito: "Eu sou vosso irmão José", mesmas palavras com que o bíblico José, do Egito, se deu a conhecer aos seus irmãos judeus. Sobre esta pequena história existe outra versão, segundo Arendt, igualmente interessante, mas talvez menos grandiosa, que teria se passado quando o papa recebeu pela primeira vez os cardeais, depois de sua eleição. ${ }^{30}$ Ambas dão mostra de seu desprendimento e da enorme humildade que o fez aceitar o cargo, em atenção à vontade de Deus.

Não foi, no entanto, perfeitamente tranqüila esta aceitação. Roncalli ficou segundo Arendt, terrivelmente preocupado ao assumir as tremendas responsabilidades das insígnias de Pedro. Contava aos seus interlocutores mais chegados que passou várias noites em claro, até que, em certa manhã, disse para si mesmo: “Giovanni [João], não te leves tão a sério!" Ficou-lhe acertado, a partir de então, que Deus providenciaria o que fosse necessário à missão que Ele próprio lhe designara, abandonando-se na fé ao Criador, que o pusera naquela posição.

Histórias como estas, verdadeiras ou não, ao serem contadas pelos fiéis cristãos, falam de um papa, o primeiro em muitos séculos, próximo deste povo, humilde e simples, de carne e osso, mostrando-lhes que, para a santidade, não há que se estar distante das criaturas de Deus, num plano mais elevado e impossível de ser alcançado pelo comum dos mortais.

No plano político, João XXIII fez mais pela Igreja que muitos de seus antecessores, mostrando um caminho a ser seguido pelos que crêem com sinceridade. A vaidade das comendas, dos títulos e da riqueza terrena não tem outro sentido do que afastar a criatura do Criador. 
Sempre se contentara com 'viver um dia de cada vez', e até 'uma hora de cada vez', como os lírios do campo e agora postulava como 'regra fundamental de conduta' do seu novo Estado 'não se preocupar com o futuro', não tomar quaisquer 'providências humanas em relação a ele' e ter o cuidado 'de não falar dele confiante e despreocupadamente a ninguém'. Foi a fé e não a teoria, teológica ou política, que o impediu de 'pactuar, fosse de que forma fosse, com o mal, na esperança de assim poder ser útil a alguém.[...] o que lhe conferia uma tal liberdade era o fato de poder dizer, sem qualquer espécie de reserva,mental ou emocional: Seja feita a Vossa vontade. ${ }^{31}$

Abandonar-se à fé - nos homens e/ou em Deus - é lidar com coisas da polis de uma posição em que o outro não é considerado um inimigo, mas, quando muito, um adversário, ou ainda mais apropriadamente, um irmão, pois todos temos uma mesma origem sobrenatural, de um passado em Deus e na entrega de seu Filho por nossos pecados.

Não desejar as coisas terras (cobiça), mas lidar na política com a caridade, torna-nos abertos ao diálogo, à conciliação e à conversão de nossos oponentes e não à tentativa de sua destruição. É a política da não-violência ativa na linha de Gandhi, Luther King, Dom Hélder Câmara e outros.

Hannah Arendt, mesmo na fase em que denunciava o totalitarismo e as barbaridades perpetradas pelo nazismo, no absurdo do ódio que vitimou tantos judeus e não-judeus, não perdeu a dimensão adquirida na juventude quanto ao valor do amor no mundo. Seus escritos apontam para a necessidade de agir, de pensar, em direção ao entendimento destes fenômenos, para que eles não voltassem a se repetir e que a humanidade pudesse chegar a perceber sua origem e seu destino no Deus de amor, conforme ensinava Santo Agostinho.

Desde a mais tenra idade

Inicia teu filho

no amor

aos horizontes largos. 


\author{
E ensina-lhe \\ a criar \\ amplos horizontes interiores, \\ preciosos, sobretudo, \\ se a vida reduzi-los \\ a uma nesga de céu.
}

Dom Hélder Câmara

Arcebispo de Recife e Olinda, Brasil, entre 1964 e 1985. 